\title{
ANALISIS KEHILANGAN TEMPERATUR PADA ASPAL HOTMIX SELAMA PERJALANAN KE LOKASI PENGHAMPARAN
}

\author{
Muhammad \\ Mahasiswa Program Doktor Ilmu Teknik, Universitas Syiah Kuala Banda Aceh \\ email:muhammad@gmail.com
}

\begin{abstract}
Abstrak
Aspal hot mix sering digunakan sebagai bahan pelapis permukaan (surface) kontruksi perkerasan jalan, di indonesia penggunaannya dari tahun ke tahun semakin meningkat, tidak terkecuali di Aceh pembangunan jalan dengan memakai Aspal hot mix sangat diperioritaskan setelah gempa dan stunami pada 26 Desember 2014, seiring pertambahan anggaran untuk kontruksi jalan baik dari sumber dana hibah luar negeri, APBN, OTSUS, MIGAS, APBA, maupun APBK. Akibat keterbatasan instalasi AMP dan jauhnya letak instalasi Aspalt Mixing Plant (AMP) dengan lokasi pekerjaan (penghamparan) salah satu penyebab banyaknya kehilangan temperatur selama perjalanan ke lokasi pekerjaan, sehingga menyebabkan turunnya kwalitas pekerjaan permukaan jalan. Untuk mengetahui kateristik kehilangan panas pada aspal hot mix dilakukan penelitian dengan membuat dua buah tempat uji, pertama terbuat dari plat baja, kedua terbuat dari plat baja dilapisi isolasi, masing-masing benda uji di isi aspal hot mix dengan temperatur sesuai dengan (Spesifikasi Umum 2010 Devisi 6 Pekerjaan Aspal), temperatur aspal hot mix diukur dengan alat pengukur suhu thermometer baik dalam posisi diam di instalasi AMP maupun dalam posisi diperjalanan pada saat pengangkutan dengan rentang $0,10,20,30$, $40,50,60,70,80,90,100,110,120,130,140,150,160,170,180,190,200,210$, 220, 230, dan 240 menit
\end{abstract}

Kata kunci: Asphalt hot mix, Temperatur, Waktu

\section{Pendahuluan}

Aspal Hot mix (Aspal Beton Campuran Panas ) dikenal sebagai bahan untuk pelapis permukaan (surface) konstruksi jalan, di Indonesia penggunaannya dari tahun ke tahun terus meningkat, tidak terkecuali di Aceh setelah Gempa dan Tsunami pada 26 Desember 2004 pembangunan infastruktur jalan dengan menggunakan aspal hot mix terjadi kemajuan yang sangat pesat dan harganyapun relative terjangkau. Untuk menjaga kwalitas pembangunan jalan tersebut tidak cepat rusak dan tahan lama dalam pemakaiannya, temperatur aspal hot mix harus memenuhi Spesifikasi Umum 2010 Devisi 6 Pekerjaan Aspal.

Salah satu penyebab utama turunnya kwalitas hasil pekerjaan infastruktur jalan selama ini adalah akibat banyaknya kehilangan temperatur selama pengangkutan, yang diakibatkan oleh kejauhan instalasi Aspalt Mixing Plant (AMP) dengan lokasi pekerjaan, sehingga permukaan jalan cepat keropos, dan rusak. Untuk mendapatkan hasil dan mutu yang baik dalam pembangunan jalan dengan aspal hot mix serta temperatur hot mix tetap terjaga sesuai spesifikasi 
teknis, misalnya untuk temperatur penuangan kedalam truk pengangkutan berkisar antara $150^{\circ} \mathrm{C}-135^{\circ} \mathrm{C}$, sedangkan rentang temperatur aspal hotmix selama pengangkutan sebelum memasukkan kedalam alat penghampar ( Finisher ) antara $150^{\circ} \mathrm{C}-130^{\circ} \mathrm{C}$ SNI 03-6721-2002. Dalam menyikapi permasalahan tersebut diperlukan penelitian dan pengujian kembali dengan konsep-konsep yang ada dengan perpaduan konsep baru, supaya dapat diketahui permasalahanpermasalahan yang terjadi serta solusinya sehingga bermanfaat bagi pemerintah khususnya bagi jasa kontruksi dan dunia usaha bidang pembangunan jalan.

\section{Tinjauan Kepustakaan}

Aspal hot mix umumnya di Indonesia digunakan sebagai lapisan perkerasan lentur pada permukaan konstruksi jalan dengan lalu lintas berat, sedang, ringan, tempat parkir, lapangan terbang dan perkerasan lainnya dalam kondisi segala macam cuaca. Campuran dan bahan materialnya terdiri dari agregat halus dengan agregat kasar, bahan pengisi (Filler), dengan bahan pengikat aspal dan bahan aditif sesuai komposisi gradasi agregat untuk campuran aspal pada suhu panas tertentu diatur oleh (Spesifikasi Umum 2010 Devisi 6 Pekerjaan Aspal) atau spesifikasi teknis Standar Nasional Indonesia (SNI) maka seringkali disebut " hot mix “. Sesuai dengan Mix Design Laston AC-WC.

\subsection{Bahan Campuran Aspal Hot Mix}

\subsubsection{Agregat}

Agregat adalah suatu bahan yang keras dan kaku yang digunakan sebagai bahan campuran hotmix dan berupa pasir, agregat kasar, agregat halus, dan debu agregat, banyaknya agregat dalam campuran hotmix pada umumnya berkisar antara $90 \%$ sampai dengan $95 \%$ terhadap total berat campuran atau $70 \%$ sampai dengan $85 \%$ terhadap total volume campuran aspal.

Agregat kasar untuk Mix Design Laston AC-WC adalah yang tertahan ayakan No.8 (2,36 mm) yang dilakukan secara basah dan harus bersih, keras, awet dan bebas dari lempung atau bahan yang tidak dikehendaki lainnya. Agregat halus dari sumber bahan manapun, harus terdiri dari pasir atau hasil pengayakan batu pecah yang lolos ayakan No.8 (2,36 mm).

\subsubsection{Bahan Pengisi (Filler) Untuk Campuran Aspal}

Bahan pengisi filler yang ditambahkan dalam campuran aspal adalah semen portland, bahan pengisi tersebut harus kering dan bebas dari gumpalan-gumpalan dan bila diuji dengan pengayakan sesuai SNI 03-1968-1990 harus mengandung bahan yang lolos ayakan No.200 (75 micron) tidak kurang dari $75 \%$ terhadap beratnya.

\subsubsection{Bahan Aspal Untuk Campuran Beraspal}

Bahan aspal yang digunakan dalam campuran hotmix ini jenis Aspal Keras Pen 60/70, pengambilan contoh bahan aspal dari tiap truk tangki harus dilaksanakan pada bagian atas, tengah dan bawah sesuai dengan SNI 06-68902002 . 


\subsubsection{Bahan Aditif Anti Penglupasan}

Aditif anti pengelupasan (anti stripping) yang dipakai dalam campuran hotmix ini, jenis Wetfix BE rentang 0,2\% - 0,3\% terhadap kadar aspal untuk meningkatkan ikatan dan menstabilkan campuran aspal terutama musin hujan.

\subsubsection{Temperatur Pembuatan dan Penghamparan Campuran}

Viskositas aspal untuk masing-masing prosudur pelaksanaan dan rentang temperature untuk Aspal Tipe I Pen 60/70 sesuai SNI 03-6721-2002 yang umumnya harus seperti dicantumkan dalam Tabel 1

\section{Tabel 1 Viskositas dan Temperatur Aspal untuk Pencampuran dan}

\section{Pemadatan}

\begin{tabular}{|c|c|c|c|}
\hline No. & Prosedur pel aksanaan & $\begin{array}{l}\text { Viskositas Aspal } \\
\text { (PA.S) }\end{array}$ & $\begin{array}{l}\text { Rentang Tempeur Aspal } \\
\text { Tipe I Pen } 60 / 70\end{array}$ \\
\hline 1 & Pencarrquram bend a uji Mars hall & 0,2 & $155+1$ \\
\hline$\overline{2}$ & Pemadatanbenda uji M ars hall & 0,4 & $145 \pm 1$ \\
\hline 3 & Pencarrquxam, dentane temperatur sasaran & $0,2-0,5$ & $15 S-145$ \\
\hline 4 & $\begin{array}{l}\text { Meruanelan canwuran aspal dari alat } \\
\text { pencampur be dalam touk }\end{array}$ & $\pm 0,5$ & $150-135$ \\
\hline 5 & Pernasolean ke alat penehampar & $0,5-1,0$ & $130-130^{-}$ \\
\hline $\bar{\sigma}$ & Pemadatan aw al (roda baj a) & $1-2$ & $145-125$ \\
\hline 7 & Pemadat an antara (roda karet) & $2-20$ & $125-100$ \\
\hline 8 & Pernadatan aklin $($ roda baja) & 20 & $=95$ \\
\hline
\end{tabular}

Temperatur adalah suatu besaran fisika yang dapat dikatakan sebagai amplitudo energi gerak atom atau molekul, energi ini disebut dengan panas yang disebabkan oleh adanya interaksi atom atau molekul. Pada dasarnya apabila terjadi perbedaan temperatur, maka energi akan berpindah dari daerah bertemperatur tinggi ke daerah bertemperatur rendah. Menurut konsep thermodinamika energi yang dipindahkan akibat perbedaan temperatur disebut dengan Perpindahan panas. Pada bab ini kita akan melihat dasar-dasar perpindahan panas dan beberapa aplikasi sederhana.

\subsubsection{Perpindahan Panas}

Tata cara Perpindahan Panas dibagi menjadi tiga, yaitu: Perpindahan Panas Konduksi (conduction); Perpindahan Panas Konveksi (convection); Perpindahan Panas Radiasi (radiation)

Perpindahan panas konduksi adalah perpindahan panas yang terjadi pada suatu media padat yang tak tembus cahaya (opaque). Bila terjadi garadien temperatur pada suatu benda maka panas akan dipindahkan dari suatu daerah yang bertemperatur tinggi ke daerah yang bertemperatur rendah, konduksi dapat terjadi pada benda padat, cair dan gas. Laju perpindahan panas konduksi qk, sebanding dengan gradien temperatur $\mathrm{dT} / \mathrm{dx}$, dikalikan dengan luas penampang dimana panas dipindahkan.

$$
\mathrm{q}_{\mathrm{k}}=\mathrm{kA} \cdot d T / d x
$$

di mana:

$$
\begin{aligned}
\mathrm{qk} & =\text { Perbedaan Temperatur }\left({ }^{0} \mathrm{C},{ }^{\circ} \mathrm{F}\right) \\
\mathrm{k} & =\text { Konduktifitas Thermal }\left(\mathrm{W} / \mathrm{m} .{ }^{0} \mathrm{C} \text { atau Btu/h } . \mathrm{ft} .{ }^{\circ} \mathrm{F}\right. \text { Laju } \\
\mathrm{A} & =\text { Luas penampang }\left(\mathrm{m}^{2}\right)
\end{aligned}
$$


$\mathrm{dT}=$ Laju perpindahan panas konduksi $(\mathrm{kj} / \mathrm{det})$

$\mathrm{dx}=$ Perbedaan Jarak $(\mathrm{m} / \mathrm{det})$

Laju aliran panas aktual tergantung pada konduktifitas thermal (k) atau sifatsifat fisik medium. Maka persamaannya dapat kita tuliskan sebagai berikut:

$\mathrm{q}_{\mathrm{k}}=-\mathrm{kA} \cdot d T / d x$

Tanda minus merupakan konsekwensi hukum kedua thermodinamika dimana panas arus mengalir ke arah temperatur yang lebih rendah. Penggambaran sederhana dari hukum Fourier yaitu perpindahan panas yang melewati dinding suatu bidang, ketika kedua permukaan dinding seragam, namun berbeda temperatur maka panas akan mengalir hanya dalam satu arah yang tegak lurus dari permukaan dinding. Jika konduktivitasnya thermalnya seragam maka intergrasi persamaan 2 akan ditunjukan:

$$
\mathrm{q}=-\mathrm{kA} / L\left(\mathrm{~T}_{2}-\mathrm{T}_{1}\right)
$$

di mana:

$\mathrm{q}=$ Laju perpindahan panas $(\mathrm{kj} / \mathrm{det})$

$\mathrm{A}=$ Luas permukaan yang kontak dengan fuida $\left(\mathrm{cm}^{2}, \mathrm{~m}^{2}\right)$

$\mathrm{L} \quad=$ Tebal dinding $(\mathrm{cm}, \mathrm{m})$

$\left(\mathrm{T}_{2}-\mathrm{T}_{1}\right)=$ Temperatur Permukaan

$\mathrm{k}=\operatorname{Konduktifitas}$ Termal $\left(\mathrm{W} / \mathrm{m} .{ }^{0} \mathrm{C}\right.$ atau Btu/h $\left.. \mathrm{ft} .{ }^{\circ} \mathrm{F}\right)$

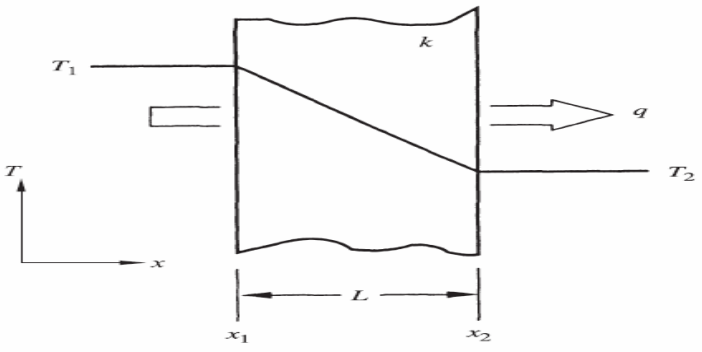

\section{Gambar 1 Distribusi suhu untuk konduksi keadaan steadi melalui dinding datar}

Untuk banyak material konduktivitas termalnya tidak seragam, tetapi berubah terhadap temperatur. Dalam beberapa kasus biasanya diambil suatu pendekatan dengan range temperatur tertentu sebagai fungsi linear temperatur:

$$
\mathrm{K}(\mathrm{T})=\mathrm{kA} \quad(1+\beta \mathrm{T})
$$

di mana: $\mathrm{k}=$ Besar konduktivitas termal temperatur tertentu

$\beta=$ Kostanta empiris

Seperti dijelaskan secara lebih dimana intergrasi pers,(2) diperoleh:

atau

$$
\mathrm{q}_{\mathrm{k}}=\mathrm{kA} / \mathrm{L}\left\{\left(\mathrm{T}_{1}-\mathrm{T}_{2}\right)+\beta / 2\left(\mathrm{~T}_{1}^{2} / \mathrm{T}_{2}^{2}\right)\right\}
$$

$\mathrm{q}_{\mathrm{k}}=\mathrm{K}_{\mathrm{m}} \cdot \mathrm{A} / \mathrm{L}\left(\mathrm{T}_{1}-\mathrm{T}_{2}\right)$

di mana $K_{m}$ merupakan besar $k$ pada temperatur rata-rata $\left(T_{1}-T_{2}\right) / 2$ 
Bahan yang mempunyai konduktivitas termal yang tinggi dinamakan konduktor (conductor), sedangkan bahan yang konduktivitas termalnya rendah disebut isolator (insulator).

\section{Metode Penelitian}

\subsection{Pengumpulan Data}

Penelitian terhadap kelihangan temperatur pada material aspal hotmix Laston AC-WC (Asphalt Concrete Wearing Course), pengujian dilakukan pada saat Aspal hotmix dituangkan kedalam benda uji baik dalam posisi diam ditempat (tidak dalam posisi berjalan) maupun dalam posisi pengangkutan (diperjalanan) hasil produksi instalasi Asphalt Mixing Plant (AMP) PT.Abad Jaya Abadi Sentosa Krueng Geukuh Kabupaten Aceh Utara.

Tabel 2 Bahan Uji Hotmix Design Laston AC-WC

\begin{tabular}{|c|c|c|c|c|c|c|}
\hline $\mathrm{NO}$ & \multicolumn{3}{|c|}{ JENIS PEMERIKSAAN } & HASIL & SPESIFIKASI & KET \\
\hline \multirow{7}{*}{1} & \multirow{7}{*}{$\begin{array}{c}\text { Composisi } \\
\text { Campuran } \\
\text { Terhadap } \\
\text { Total } \\
\text { Agregat }(\%)\end{array}$} & \multicolumn{2}{|c|}{ Coarse Aggregat } & 10 & $3 / 4 ", 1 / 2 ", 3 / 8 "$ & Batu Pecah \\
\hline & & \multicolumn{2}{|c|}{ Madium Aggregat } & 28 & No.4 No.8 & B. Pecah halus \\
\hline & & \multicolumn{2}{|c|}{ Fine Aggregat } & 43 & $16,30,50,100$ & Dust \\
\hline & & \multicolumn{2}{|c|}{ Natural Sand } & 15 & $16,30,50,100$ & Pasir \\
\hline & & \multicolumn{2}{|c|}{ Filler } & 4 & N0.200 & Semen PC \\
\hline & & \multicolumn{2}{|c|}{ Additive } & 0,3 & & Aditif \\
\hline & & \multicolumn{2}{|c|}{ Aspal Optimum(\%) } & 5,66 & & Aspal \\
\hline \multirow{11}{*}{2} & \multirow{11}{*}{$\begin{array}{c}\text { Gradasi } \\
\text { Campuran } \\
(\%)\end{array}$} & ASTM & $\mathrm{mm}$ & & & \multirow{11}{*}{$\begin{array}{c}\text { Spesipikasi } \\
\text { Bergradasi } \\
\text { Halus }\end{array}$} \\
\hline & & $3 / 4 "$ & 19,0 & 99,68 & $100-100$ & \\
\hline & & $1 / 2 "$ & 12,5 & 90,94 & $90-100$ & \\
\hline & & $3 / 8 "$ & 9,50 & 72,19 & $72-80$ & \\
\hline & & No.4 & 4,75 & 60,20 & $54-69$ & \\
\hline & & No.8 & 2,36 & 52,43 & $39,1-53$ & \\
\hline & & No.16 & 1,18 & 40,78 & $31,6-40$ & \\
\hline & & No.30 & 0,60 & 26,57 & $23,1-40$ & \\
\hline & & No.50 & 0,30 & 15,63 & $15,5-22$ & \\
\hline & & No.100 & 0,15 & 5,30 & $9-15$ & \\
\hline & & \multirow{2}{*}{\multicolumn{2}{|c|}{\begin{tabular}{c|c} 
No.200 & 0,075 \\
\% Berat isi Campuran
\end{tabular}}} & 4,71 & $4-10$ & \\
\hline \multirow{8}{*}{3} & \multirow{8}{*}{$\begin{array}{l}\text { Marshall } \\
\text { Test }\end{array}$} & & & 2,36 & & \\
\hline & & \multicolumn{2}{|c|}{$\begin{array}{c}\text { \% Rongga Dlm } \\
\text { Campuran }\end{array}$} & 3,81 & $3,5-5,5$ & VIM \\
\hline & & \multicolumn{2}{|c|}{$\begin{array}{l}\text { \% Rongga Dlm } \\
\text { Campuran }\end{array}$} & 3,10 & Min 2,5 & $\begin{array}{l}\text { VIM dari } \\
\text { refusal }\end{array}$ \\
\hline & & \multicolumn{2}{|c|}{$\begin{array}{c}\% \text { Rongga Dlm } \\
\text { Agregat }\end{array}$} & 16,20 & Min 14 & VMA \\
\hline & & \multicolumn{2}{|c|}{$\begin{array}{c}\% \text { Rongga Terisi } \\
\text { Aspal }\end{array}$} & 76,51 & Min 63 & VFB \\
\hline & & \multicolumn{2}{|c|}{ Stabilitas (kg) } & 1382,90 & Min 800 & \\
\hline & & \multicolumn{2}{|c|}{ Flow $(\mathrm{mm})$} & 3,15 & Min 3 & \\
\hline & & \multicolumn{2}{|c|}{ Marshall Quotient } & 436,10 & $\operatorname{Min} 250$ & MQ \\
\hline
\end{tabular}

Peralatan adalah alat yang digunakan pada saat pengujian misalnya: Tempat uji terbuat besi plat baja 100 x 100 x $40 \mathrm{~cm}$ dan isolasi bahan kayu seperti tampak pada gambar. 


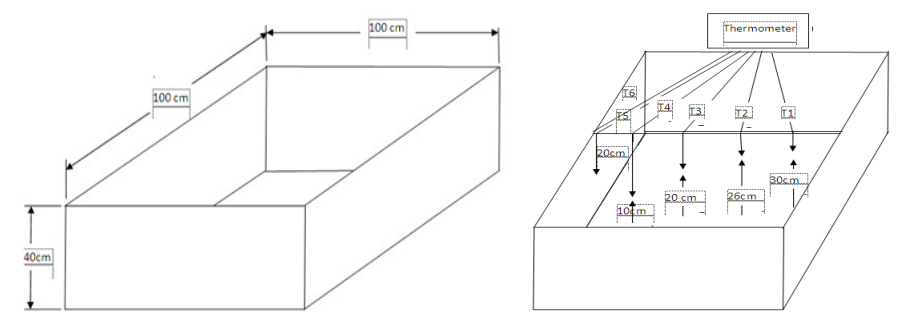

\section{Gambar 2 Desain tempat benda uji dan instalasi titik-titik pengujian ke thermometer.}

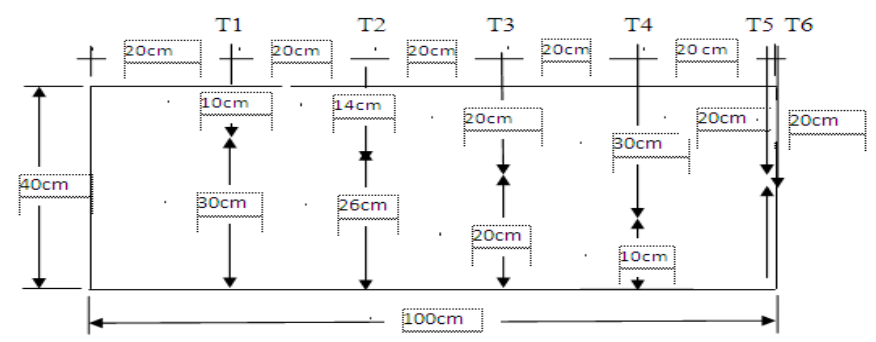

\section{Gambar 3 Desain instalasi titik-titik pengujian pada tempat benda uji}

Rentang temperatur pengujian yang akan diamati dalam hitungan menit dengan menggunakan pengukur suhu (thermometer) yaitu: $0,10,20,30,40,50$, $60,70,80,90,100,110,120,130,140,150,160,170,180,190,200,210,220,230$, dan 240 menit.

\section{Hasil dan Pembahasan}

Pengukuran temperatur dilakukan secara eksperimental, dimana titik-titik pengukuran bahan uji diambil setelah dituangkan campuran aspal hotmix dari instalasi AMP kedalam tempat uji yang sudah disediakan dilokasi AMP dan sampai dilokasi perkerasan sebelum dimasukan kedalam alat penghampar sesuai dengan rentang temperatur spesifikasi teknis SNI 03-6721-2002 (Spesifikasi Umum Divisi 6 Perkerasan Aspal Tahun 2010). Untuk mendapatkan hasil yang maksimal dalam proses penelitian ini secara umum dilaksanakan secara berurutan dan sistematis untuk menganalisis kehilangan temperatur pada aspal hotmix selama dalam perjalanan maupun dalam posisi diam (tidak bergerak) dibuat dua buah tempat uji dan di isi aspal hot mix sesuai dengan rentang temperatur spesifikasi teknis SNI 03-6721-2002 (Spesifikasi Umum Divisi 6 Perkerasan Aspal Tahun 2010), pencatatan temperatur dilakukan 4 (empat) kali di mana:

1. 1 (satu) kali benda uji plat baja di perjalanan.

2. 1 (satu) kali benda uji plat baja posisi diam di instalasi AMP.

3. 1 (satu) kali benda uji plat dilapisi isolasi dari kayu (Plywood) di perjalanan.

4. 1 (satu) kali dalam benda uji dari kayu (Plywood) posisi diam di Instalasi AMP.

Dengan menggunakan alat pengukur temperatur thermometer dan, pengukur waktu seperti hasil sebagai berikut: 
Pengujian : Aspal Hot Mix AC-WC Produksi AMP PT Abad Jaya Abadi Sentosa

Mulai Pukul : $11.30 \mathrm{Wib}$

Selesai Pukul : $15.30 \mathrm{Wib}$

Tes (Posisi) : Diperjalanan berat material $700 \mathrm{~kg}$

Peralatan Uji : Kotak Plat Baja 2,5mm tanpa isolasi

Tabel 3 Rentang Temperatur Aspal Hotmix

Hasil Pengujian (Suhu Ruang: 30-32 ${ }^{\circ} \mathrm{C}$ )

\begin{tabular}{|c|c|c|c|c|c|c|c|c|}
\hline No & $\begin{array}{c}\text { Waktu } \\
\text { (Menit) }\end{array}$ & $\begin{array}{l}\mathbf{T} 1 \\
{ }^{\circ} \mathbf{C}\end{array}$ & $\begin{array}{l}{ }^{\mathrm{T} 2} \\
{ }^{\circ} \mathrm{C}\end{array}$ & $\begin{array}{l}\mathbf{T 3} \\
{ }^{\circ} \mathbf{C}\end{array}$ & $\begin{array}{l}\mathrm{T} 4 \\
{ }^{\circ} \mathrm{C}\end{array}$ & $\begin{array}{l}\mathrm{T5} \\
{ }^{\circ} \mathrm{C}\end{array}$ & $\begin{array}{l}\text { T6 } \\
{ }^{\circ} \mathrm{C}\end{array}$ & KET \\
\hline 1 & 2 & 3 & 4 & 5 & 6 & 7 & 8 & 9 \\
\hline 1 & 0 & 156,4 & 162,9 & 155,3 & 159,2 & 105,9 & 94,2 & \\
\hline 2 & 10 & 157,9 & 164,6 & 156,2 & 159,3 & 96,8 & 87,3 & \\
\hline 3 & 20 & 158,2 & 165,3 & 157,7 & 158,2 & 81,7 & 70,0 & \\
\hline 4 & 30 & 155,2 & 163,1 & 156,4 & 155,2 & 71,5 & 63,3 & \\
\hline 5 & 40 & 153,0 & 162,1 & 155,9 & 153,8 & 67,9 & 61,2 & \\
\hline 6 & 50 & 154,2 & 163,2 & 157,2 & 153,6 & 67,3 & 58,6 & \\
\hline 7 & 60 & 151,4 & 161,6 & 155,6 & 151,1 & 63,4 & 57,9 & \\
\hline 8 & 70 & 150,4 & 162,0 & 156,3 & 152,3 & 63,6 & 54,0 & \\
\hline 9 & 80 & 149,0 & 161,7 & 155,2 & 151,9 & 59,7 & 52,3 & \\
\hline 10 & 90 & 147,3 & 162,0 & 156,6 & 152,0 & 57,4 & 48,6 & \\
\hline 11 & 100 & 146,3 & 162,0 & 156,8 & 151,9 & 60,4 & 50,5 & \\
\hline 12 & 110 & 143,5 & 160,4 & 155,2 & 150,2 & 56,5 & 49,9 & \\
\hline 13 & 120 & 141,5 & 160,1 & 154,9 & 149,8 & 55,4 & 48,3 & \\
\hline 14 & 130 & 139,5 & 158,6 & 153,6 & 148,2 & 56,4 & 49,0 & \\
\hline 15 & 140 & 139,2 & 159,6 & 154,3 & 148,8 & 55,7 & 49,7 & \\
\hline 16 & 150 & 137,3 & 158,3 & 153,4 & 147,7 & 53,4 & 46,0 & \\
\hline 17 & 160 & 135,3 & 157,5 & 152,4 & 146,0 & 50,6 & 45,0 & \\
\hline 18 & 170 & 133,0 & 157,1 & 152,0 & 145,9 & 51,2 & 43,9 & \\
\hline 19 & 180 & 132,7 & 156,2 & 152,3 & 146,0 & 55,0 & 47,4 & \\
\hline 20 & 190 & 130,3 & 155,4 & 150,7 & 143,9 & 51,4 & 43,7 & \\
\hline 21 & 200 & 129,2 & 155,1 & 150,6 & 143,3 & 50,6 & 43,9 & \\
\hline 22 & 210 & 127,5 & 154,1 & 149,4 & 141,9 & 48,8 & 41,8 & \\
\hline 23 & 220 & 126,2 & 153,3 & 149,0 & 141,3 & 51,2 & 43,3 & \\
\hline 24 & 230 & 124,5 & 152,7 & 148,2 & 140,1 & 48,0 & 40,4 & \\
\hline 25 & 240 & 123,0 & 151,8 & 147,3 & 138,8 & 48,7 & 42,8 & \\
\hline
\end{tabular}

Not: T5 Temperatur dinding benda uji bagian dalam

T6 Temperatur dinding benda uji bagian luar

Dari tabel hasil pencatatan diatas dapat dilihat kehilangan temperatur pada aspal hot mix selama perjalanan pada benda uji dari plat baja, adalah pada bagian dalam samping kanan T5 yang paling banyak kehilangan temperatur, sedangkan bagian kiri atas T2 yang paling sedikit kehilangan temperatur aspal hot mix, untuk lebih jelasnya lihat tabel di atas. 
Pengujian : Aspal Hot Mix AC-WC Produksi AMP. PT Abad Jaya Abadi Sentosa

Mulai Pukul : $10.30 \mathrm{Wib}$

Selesai Pukul : $14.30 \mathrm{Wib}$

Tes (Posisi) : Diam berat material $700 \mathrm{~kg}$

Peralatan Uji : Kotak Plat Baja 2,5mm

Tabel 4 Rentang Temperatur Aspal Hotmix

Hasil Pengujian (Suhu Ruang : 31-33 ${ }^{\circ} \mathrm{C}$ )

\begin{tabular}{|c|c|c|c|c|c|c|c|c|}
\hline No & $\begin{array}{c}\text { Waktu } \\
\text { (Menit) }\end{array}$ & $\begin{array}{l}{ }^{\mathbf{T} 1} \\
{ }^{\circ} \mathbf{C}\end{array}$ & $\begin{array}{l}\mathrm{T} 2 \\
{ }^{\circ} \mathrm{C}\end{array}$ & $\begin{array}{l}\text { T3 } \\
{ }^{\circ} \mathbf{C}\end{array}$ & $\begin{array}{l}\mathrm{T} 4 \\
{ }^{\circ} \mathrm{C}\end{array}$ & $\begin{array}{l}\text { T5 } \\
{ }^{\circ} \mathrm{C}\end{array}$ & $\begin{array}{l}\text { T6 } \\
{ }^{\circ} \mathrm{C}\end{array}$ & KET \\
\hline 1 & 2 & 3 & 4 & 5 & 6 & 7 & 8 & 9 \\
\hline 1 & $\overline{0}$ & 152,9 & 155,5 & 159,1 & 160,3 & 111,0 & 92,0 & . \\
\hline 2 & 10 & 152,1 & 157,2 & 156,6 & 158,1 & 105,6 & 90,3 & \\
\hline 3 & 20 & 153,9 & 158,4 & 157,8 & 160,1 & 107,6 & 95,6 & \\
\hline 4 & 30 & 153,3 & 160,1 & 159,9 & 161,6 & 106,5 & 93,2 & \\
\hline 5 & 40 & 157,2 & 161,8 & 161,1 & 160,7 & 107,1 & 91,1 & \\
\hline 6 & 50 & 155,5 & 160,7 & 160,6 & 159,2 & 95,7 & 81,8 & \\
\hline 7 & 60 & 155,0 & 160,3 & 160,4 & 158,5 & 92,0 & 79,6 & \\
\hline 8 & 70 & 155,0 & 160,2 & 160,3 & 158,4 & 92,0 & $79 ; 1$ & \\
\hline 9 & 80 & 154,4 & 159,4 & 159,6 & 155,9 & 89,3 & 77,7 & \\
\hline 10 & 90 & 153,2 & 158,4 & 158,7 & 154,2 & 86,0 & 74,0 & \\
\hline 11 & 100 & 152,9 & 158,2 & 158,6 & 153,1 & 86,6 & 75,9 & \\
\hline 12 & 110 & 154,0 & 159,4 & 160,1 & 153,6 & 85,5 & 80,8 & \\
\hline 13 & 120 & 154,3 & 159,7 & 160,3 & 153,9 & 88,0 & 79,4 & \\
\hline 13 & 130 & 152,9 & 158,9 & 159,6 & 151,5 & 87,3 & 79,6 & \\
\hline 15 & 140 & 154,6 & 161,1 & 162,0 & 153,1 & 88,1 & 78,9 & \\
\hline 16 & 150 & 153,7 & 160,2 & 161,4 & 151,3 & 86,1 & 79,0 & \\
\hline 17 & 160 & 152,4 & 158,5 & 159,5 & 149,5 & 82,3 & 72,9 & \\
\hline 18 & 170 & 151,6 & 157,9 & 158,8 & 148,7 & 82,2 & 74,7 & \\
\hline 19 & 180 & 151,3 & 158,2 & 157,1 & 146,4 & 82,0 & 74,0 & \\
\hline 20 & 190 & 152,8 & 157,0 & 156,0 & 145,3 & 80,4 & 72,3 & \\
\hline 21 & 200 & 150,9 & 156,0 & 155,1 & 144,3 & 79,8 & 72,1 & \\
\hline 22 & 210 & 151,5 & 155,5 & 154,6 & 143,3 & 77,7 & 70,1 & \\
\hline 23 & 220 & 149,8 & 154,8 & 153,7 & 142,7 & 75,4 & 69,2 & \\
\hline 24 & 230 & 148,8 & 153,9 & 153,0 & 140,9 & 72,8 & 66,6 & \\
\hline 25 & 240 & 147,1 & 152,1 & 152,3 & 139,2 & 71,1 & 65,2 & \\
\hline
\end{tabular}

Not: T5 Temperatur dinding benda uji bagian dalam

T6 Temperatur dinding benda uji bagian luar

Dari tabel 4 hasil pencatatan diatas dapat dilihat kehilangan temperatur pada aspal hot mix selama dalam posisi diam pada benda uji yang terbuat dari plat baja tebal $2,5 \mathrm{~cm}$ ukuran $100 \times 100 \times 40 \mathrm{~cm}$, adalah bagian dinding dalam samping kanan benda uji (T5) yang paling banyak kehilangan temperatur, sedangkan bagian kiri atas benda uji (T3) yang paling sedikit kehilangan temperatur pada aspal hot mix. 
Pengujian : Hotmix Laston AC-WC Produksi AMP. PT Abad Jaya Abadi Sentosa

Mulai Pukul : 10.15 Wib

Selesai Pukul : $14.15 \mathrm{Wib}$

Tes (Posisi) : Diperjalanan berat material $700 \mathrm{~kg}$

Peralatan Uji : Plat Baja 2,5 mm dengan Isolasi (Plywood $8 \mathrm{~mm}$ )

Tabel 5 Rentang Temperatur Aspal Hotmix Hasil Pengujian (Suhu Ruang : 29-32 ${ }^{\circ} \mathrm{C}$ )

\begin{tabular}{|c|c|c|c|c|c|c|c|c|}
\hline No & $\begin{array}{c}\text { Waktu } \\
\text { (Menit) }\end{array}$ & $\begin{array}{c}\text { T1 } \\
{ }^{\circ} \mathbf{C}\end{array}$ & $\begin{array}{c}\text { T2 } \\
{ }^{\circ} \mathbf{C}\end{array}$ & $\begin{array}{c}{ }^{\mathbf{T}} \mathbf{C} \\
{ }^{\circ}\end{array}$ & $\begin{array}{c}\text { T4 } \\
{ }^{\circ} \mathbf{C}\end{array}$ & $\begin{array}{c}\text { T5 } \\
{ }^{\circ} \mathbf{C}\end{array}$ & $\begin{array}{c}\text { T6 } \\
{ }^{\circ} \mathbf{C}\end{array}$ & KET \\
\hline 1 & 2 & 3 & 4 & 5 & 6 & 7 & 8 & 9 \\
\hline 2 & 10 & 155,4 & 155,5 & 155,7 & 159,1 & 116,6 & 58,9 & \\
\hline 3 & 20 & 158,1 & 159,4 & 158,1 & 153,7 & 116,1 & 69,4 & \\
\hline 4 & 30 & 156,6 & 160,0 & 157,6 & 154,0 & 115,0 & 54,1 & \\
\hline 5 & 40 & 156,1 & 159,1 & 156,9 & 153,3 & 111,7 & 50,1 & \\
\hline 6 & 50 & 155,6 & 158,6 & 156,4 & 152,8 & 111,0 & 50,5 & \\
\hline 7 & 60 & 155,7 & 158,7 & 156,5 & 152,6 & 109,1 & 50,7 & \\
\hline 8 & 70 & 136,1 & 159,1 & 156,7 & 152,6 & 108,5 & 50,6 & \\
\hline 9 & 80 & 136,2 & 159,1 & 156,7 & 152,1 & 107,7 & 50,1 & \\
\hline 10 & 90 & 136,1 & 159,0 & 156,7 & 151,6 & 105,9 & 50,4 & \\
\hline 11 & 100 & 136,0 & 159,1 & 156,9 & 151,3 & 103,8 & 49,7 & \\
\hline 12 & 110 & 138,8 & 158,2 & 155,9 & 149,5 & 105,1 & 49,0 & \\
\hline 13 & 120 & 138,9 & 158,4 & 156,3 & 149,2 & 103,1 & 46,6 & \\
\hline 14 & 130 & 138,5 & 156,1 & 154,0 & 145,0 & 102,7 & 55,0 & \\
\hline 15 & 140 & 138,0 & 155,1 & 153,8 & 144,7 & 102,5 & 54,9 & \\
\hline 16 & 150 & 137,7 & 155,0 & 153,1 & 144,1 & 102,4 & 55,0 & \\
\hline 17 & 160 & 137,1 & 154,7 & 153,7 & 144,0 & 102,2 & 53,8 & \\
\hline 18 & 170 & 136,7 & 154,5 & 153,7 & 143,9 & 102,1 & 47,4 & \\
\hline 19 & 180 & 136,3 & 154,3 & 153,1 & 143,7 & 100,3 & 49,6 & \\
\hline 20 & 190 & 136,0 & 154,0 & 153,0 & 142,5 & 99,7 & 47,4 & \\
\hline 21 & 200 & 135,1 & 153,9 & 152,7 & 141,3 & 99,2 & 45,4 & \\
\hline 22 & 210 & 134,7 & 153,5 & 151,3 & 139,3 & 94,3 & 44,3 & \\
\hline 23 & 220 & 133,4 & 152,4 & 150,0 & 137,7 & 94,9 & 45,6 & \\
\hline 24 & 230 & 132,2 & 151,6 & 150,7 & 137,8 & 94,8 & 45,7 & \\
\hline 25 & 240 & 131,9 & 149,2 & 148,6 & 135,5 & 92,8 & 45,8 & \\
\hline
\end{tabular}

Not: T5 Temperatur dinding kanan dalam benda uji

T6 Temperatur dinding bagian kanan luar benda uji

Dari tabel 5 hasil pencatatan diatas dapat dilihat kehilangan temperatur pada aspal hot mix selama dalam posisi diam pada benda uji dari plat baja 2,5 $\mathrm{mm}$ yang dlapisi isolasi dari papan kayu (plywood) tebal $8 \mathrm{~mm}$ ukuran $100 \times 100 \times 40 \mathrm{~cm}$, adalah pada bagian dalam samping kanan benda uji (T5) paling banyak kehilangan temperatur, sedangkan bagian kiri atas benda uji (T3) paling sedikit kehilangan temperatur, sedangkan temperatur (T6) bagian dinding kanan luar yang berhadapan langsung dengan suhu ruang $29-32{ }^{\circ} \mathrm{C}$ sangat jauh berbeda, rata-rata $30-40{ }^{\circ} \mathrm{C}$ untuk lebih jelasnya lihat tabel di atas. 
Pengujian : Aspal Hot Mix AC-WC Produksi AMP PT Abad Jaya Abadi Sentosa

Mulai Pukul : $9.00 \mathrm{Wib}$

Selesai Pukul : $13.00 \mathrm{Wib}$

Tes (Posisi) : Diam berat material $700 \mathrm{~kg}$

Peralatan Uji : Kotak Uji Plat Baja 2,5 mm Isolasi ( Plywood 8 mm )

Tabel 6 Rentang Temperatur Aspal Hotmix Hasil Pengujian (Suhu Ruang: 29-32 ${ }^{\circ} \mathrm{C}$ )

\begin{tabular}{|c|c|c|c|c|c|c|c|c|}
\hline No & $\begin{array}{c}\text { Waktu } \\
\text { (Menit) }\end{array}$ & $\begin{array}{l}\mathbf{T 1} \\
{ }^{\circ} \mathbf{C}\end{array}$ & $\begin{array}{l}\mathrm{T} 2 \\
{ }^{\mathrm{T}} \mathrm{C}\end{array}$ & $\begin{array}{l}\mathbf{T 3} \\
{ }^{\mathbf{T}} \mathrm{C}\end{array}$ & $\begin{array}{l}\mathrm{T4} \\
{ }^{\circ} \mathrm{C}\end{array}$ & $\begin{array}{l}\mathrm{T} 5 \\
{ }^{\circ} \mathrm{C}\end{array}$ & $\begin{array}{l}\mathrm{T6} \\
{ }^{\mathrm{T}} \mathrm{C}\end{array}$ & KET \\
\hline 1 & 2 & 3 & 4 & 5 & 6 & 7 & 8 & 9 \\
\hline 1 & 0 & 156,3 & 159,2 & 164,7 & 157,3 & 122,8 & 81,2 & \\
\hline 2 & 10 & 150,3 & 154,8 & 155,6 & 155,0 & 122,4 & 88,5 & \\
\hline 3 & 20 & 150,5 & 154,7 & 154,8 & 154,5 & 121,9 & 82,3 & \\
\hline 4 & 30 & 150,5 & 154,4 & 154,3 & 153,5 & 121,8 & 80,1 & \\
\hline 5 & 40 & 150,0 & 154,0 & 154,0 & 153,7 & 120,7 & 80,7 & \\
\hline 6 & 50 & 151,2 & 154,8 & 154,9 & 154,4 & 120,5 & 80,4 & \\
\hline 7 & 60 & 151,0 & 154,9 & 155,0 & 153,6 & 18,5 & 80,6 & \\
\hline 8 & 70 & 150,3 & 154,0 & 153,9 & 151,7 & 116,3 & 76,6 & \\
\hline 9 & 80 & 148,9 & 152,8 & 152,7 & 151,6 & 115,6 & 76,0 & \\
\hline 10 & 90 & 148,3 & 152,9 & 153,4 & 150,5 & 114,7 & 75,4 & \\
\hline 11 & 100 & 148,1 & 153,1 & 153,1 & 149,5 & 113,8 & 75,2 & \\
\hline 12 & 110 & 147,8 & 152,9 & 153,1 & 148,6 & 110,5 & 73,8 & \\
\hline 13 & 120 & 147,4 & 153,4 & 152,7 & 147,2 & 108,4 & 72,8 & \\
\hline 14 & 130 & 149,5 & 154,5 & 154,6 & 148,8 & 110,3 & 72,2 & \\
\hline 15 & 140 & 147,3 & 153,2 & 153,8 & 147,9 & 105,9 & 70,5 & \\
\hline 16 & 150 & 147,2 & 153,7 & 154,2 & 147,7 & 105,4 & 69,8 & \\
\hline 17 & 160 & 148,5 & 155,1 & 155,7 & 148,4 & 104,5 & 69,7 & \\
\hline 18 & 170 & 145,9 & 153,1 & 153,8 & 145,9 & 104,1 & 69,7 & \\
\hline 19 & 180 & 145,3 & 153,4 & 154,3 & 145,6 & 103,3 & 69,2 & \\
\hline 20 & 190 & 143,5 & 151,4 & 152,3 & 142,6 & 101,5 & 67,7 & \\
\hline 21 & 200 & 144,8 & 153,3 & 154,3 & 144,1 & 101,1 & 67,5 & \\
\hline 22 & 210 & 144,0 & 152,7 & 153,8 & 143,2 & 100,4 & 67,3 & \\
\hline 23 & 220 & 143,2 & 152,0 & 153,6 & 141,7 & 100,0 & 66,7 & \\
\hline 24 & 230 & 143,2 & 152,2 & 153,4 & 141,6 & 99,7 & 66,2 & \\
\hline 25 & 240 & 142,7 & 152,4 & 153,4 & 140,9 & 99,9 & 65,8 & \\
\hline
\end{tabular}

Not: T5 Temperatur dinding benda uji bagian dalam

T6 Temperatur dinding benda uji bagian luar

Dari tabel 6 hasil pencatatan diatas dapat dilihat kehilangan temperatur pada aspal hot mix pada benda uji $100 \times 100$ x $40 \mathrm{Cm}$ terbuat dari plat baja dilapisi isolasi dalam posisi diam, adalah bagian dalam samping kanan dalam benda uji (T5) yang paling banyak kehilangan temperatur, sedangkan bagian kiri atas benda uji (T3) yang paling sedikit kehilangan temperatur aspal hot mix, sedangkan temperatur (T6) dalah temperatur dingding benda uji kanan luar yang berhadapan langsung dengan suhu ruang $29-32{ }^{\circ} \mathrm{C}$ sangat jauh berbeda rata-rata $30-40{ }^{\circ} \mathrm{C}$ untuk lebih jelasnya lihat tabel di atas. 


\section{Kesimpulan dan Saran}

Dari hasil penelitian untuk mempertahankan temperatur aspal hot mix selama perjalanan kelokasi penghamparan sesuai dengan (Spesifikasi Umum 2010 Devisi 6 Pekerjaan Aspal), misalnya untuk temperatur penuangan dari instalasi AMP kedalam truk pengangkutan, temperatur aspal hot mix berkisar antara $150^{\circ} \mathrm{C}-135^{\circ} \mathrm{C}$, sedangkan rentang temperatur aspal hot mix selama pengangkutan sebelum memasukkan kedalam alat penghampar (Finisher) antara $150^{\circ} \mathrm{C}-130^{\circ} \mathrm{C}$ SNI 03-6721-2002. Jadi dari keempat sampel pencatatan temperatur diatas dapat disimpulkan bahwa pemakaian isolasi pada dinding truk pengangkut aspal hot mix dapat mempertahankan temperatur walaupun instalasi AMP berjauhan dengan lokasi pekerjaan.

\section{Daftar Kepustakaan}

Departen Pekerjaan Umum 1999, Pedoman Perencanaan Campuran Beraspal Panas Dengan Pendekatan Kepadatan Mutlak Jakarja: PT. Mediatama Sapta Karya PT Medisa.

Frank Kreith, 1997, Prinsip Perpindahan Panas, edisi 3, Erlangga,Jakarta. J.P. Holman, 1997, Perpindahan Kalor, edisi. 6, Erlangga, Jakarta .

Kementrian Pekerjaan Umum Direktorat Jenderal Bina Marga, 2010, Spesifikasi Umum Divisi 6 Perkerasan Aspal Tahun 2010.

Michael J. Moran, 2007, Hukum Kedua Thermodinamika, Edisi Jilit 2 Erlangga.

Sukirman, 2003, Beton Aspal Campuran Panas, Jakarta Granik. Yunus A.Cengel.Afshin J.Ghajar, 1998. Heat And Mass Transfeer. 